\title{
Anti-Breast Cancer Activity on MCF-7 Cells of Melittin from Indonesia's Apis cerana: An In Vitro Study
}

\author{
Kenny Lischer*, Shania Rosita Angelica Sitorus, Brian Wirawan Guslianto, \\ Forbes Avila, Apriliana Cahya Khayrani, Muhamad Sahlan
}

\begin{abstract}
Objective: Breast cancer is the most common case of cancers. Apitheraphy has been traditionally used for abundance diseases. This study aims to evaluate and compare the anti-breast cancer activity of melittin from Indonesia's Apic cerana as a potential drug for treating breast cancer. Methods: Apis cerana bee venom (BV) was collected from a bee farm in Cikurutung, Bandung using an electrical venom device. The BV was then purified using the ÄKTA Start system and HiTrap ${ }^{\text {TM }}$ SP HP cation exchange chromatography column. Sodium dodecyl sulfate-polyacrylamide gel electrophoresis (SDS-PAGE) was used to identify melittin based on its molecular mass and lowry's protein assay to measure melittin concentration. Melittin cytotoxicity was measured with brine shrimp lethality test (BSLT), while MCF-7 breast cancer cells MTT assay was used to measure its anti-breast cancer activity, based on inhinition rate. Results: $95.432 \mu \mathrm{g} / \mathrm{mL}$ melittin is purified from $62.8 \mathrm{mg} / \mathrm{L} \mathrm{BV}$, using cation exchange chromatography. Melittin in vitro analysis with MCF-7 MTT assay is used to determine anti-breast cancer activity in dose dependent manner. Furthermore, melttin BSLT result showed a $\mathrm{LC}_{50} 16.67675 \mu \mathrm{g} / \mathrm{mL}$. Therefore, the MTT assay was conducted in 5,10 and $15 \mu \mathrm{g} / \mathrm{mL}$ with MCF-7 inhibition values of $0.768 \pm 0.014,3.303 \pm 0.011$, and $35.714 \pm 0.009 \%$, respectively. Conclusion: Indonesia's Apis cerana has the potential to be used as a therapeutic peptide for breast cancer treatment.
\end{abstract}

Keywords: Apis cerana- anti-cancer- MCF-7 cells- Melittin

Asian Pac J Cancer Prev, 22 (12), 3913-3919

\section{Introduction}

According to a 2020 study carried out by the World Health Organization (WHO), International Agency for Research on Cancer (IARC) and Global Cancer Observatory (GLOBOCAN), every year, approximately 19.3 million people across 185 countries suffer 138 types of cancer with 10.0 million deaths. The most common type is female breast cancer (2.26 million), followed by lung (2.21 million), and prostate (1.41 million) (Ferlay et al., 2021). Meanwhile, Sung et al. (2021) stated that the most common type of cancer in 2019 was associated with the lung. The most common causes of cancer mortality in 2020 was lung (1.79 million), liver $(830,000)$, stomach $(769,000)$, and female breast cancer $(685,000)$ (Ferlay et al., 2021). Indonesia recorded about 396,914 numbers of new cancer cases and 234,511 deaths in 2020. According to the Global Cancer Observatory (2021), the most frequent number of cancer cases in 2020 was female breast cancer $(65,858)$, cervix $(36,633)$, and lung $(34,783)$. Meanwhile, in terms of mortality, the rates were lung $(30,843)$, breast $(22,430)$, and cervix $(21,003)$. Therefore, from the data above, it can be concluded that breast cancer is the most common type of cancer both internationally and in Indonesia.

The first real breakthrough for cancer therapy was found after the Second World War (WWII) with the discovery of cytotoxic antitumor drugs and the inception of chemotherapy (Falzone et al., 2018). Since then, many studies have been carried out to improve and modify chemotherapy, using other substances such as monoclonal antibodies (mAB) (Boyiadzis and Foon, 2008; Hara et al., 2020), CRISPR/Cas enzymes (Huang et al., 2018), plants (Hussain et al., 2020; Koohpar et al., 2015), and animal derived substances (Ceremuga et al., 2020).

Apitherapy is a traditional medicine that uses bee sting and beehive products to treat cancer patients (Trumbeckaite et al., 2015). Beehive products have a high level of bioactivity and consist of honey, propolis, royal jelly, bee pollen, and bee venom (BV) (Cornara et al., 2017). The use of bee venom therapy (BVT) as complementary and alternative treatment method has existed for more than 3,000 years. BV contain a very complex mixture of peptides, enzymes, biologically active amines, and nonpeptide components with various pharmaceutical properties (Gaber et al., 2020; Zhang et al., 2018). Lee et al., (2020), Lin and Hsieh (2020) and Tacón (2016) stated that BV has pain-relief, anti-inflammatory, 
antimicrobial, antivirus, and anticancer activity. BV had been studied for many forms of cancer treatment such as ovarian (Moga et al., 2018), cervical (Alalawy et al., 2020), lung (Bagyalakshmi et al., 2019), prostate (Badawi, 2021), liver (Badria et al., 2017), breast (Badria et al., 2017; Duffy et al., 2020), etc. However, the direct use of $\mathrm{BV}$ as a treatment process, lack efficacy, compared to its refined products.

According to Chen et al., (2016) and Gaber et al., (2020), Melittin is a 26 amino-acid polypeptide that accounts for $40-50 \%$ of dry BV. It is a water-soluble, linear, cationic, hemolytic, and amphipathic peptide weighting $2.840 \mathrm{kDa}$ (Fidelio et al., 1984). Furthermore, it is also the most bioactive compound in $\mathrm{BV}$, with vast bioactivity usable in broad modern medical therapies (Ceremuga et al., 2020). Generally, melittin has non-selective cytolytic activities that physically and chemically disrupt phospholipid bilayers in prokaryotic, eukaryotic, and virus membrane (Lima et al., 2021; Memariani et al., 2020; Rady et al., 2017; Watala and Gwoździński, 1992). It also binds negatively charged membrane surfaces, thereby leading to pore formation and leakage of ions and molecules, which also increases permeability and membrane lysis (Jamasbi et al., 2015).

Studies on melittin have been carried out on many form of cancer treatment such as leukemia (Ceremuga et al., 2020; Hait et al., 1985), non-small-cell lung cancer (Gao et al., 2018), glioblastoma (Sisakht et al., 2017), ovarian (Jo et al., 2012), cervical (Zarrinnahad et al., 2018), pancreatic (Wang et al., 2017), breast cancers (Duffy et al., 2020; Jeong et al., 2014), etc. One of the advantages of using Melittin as a cancer chemotheraphy replacement is its pore-forming mechanism, ability to destroy more tumors and inability to cancer cells to develop resistance (Schweizer, 2009; Soman et al., 2008).

Several studies have stated that Apis mellifera melittin is used to carry out anti-breast cancer activity in Europe and Korea (Duffy et al., 2020; Jeong et al., 2014), however, there are none on the use of Apis cerana melittin. Apis cerana BV have a more defensive peptide comaper to Apis melifera (Park et al., 2014). We want to elucidate the potential of Indonesia's Apis cerana melittin anti-breast cancer activity.

\section{Materials and Methods}

\section{BV Harvest}

The BV was collected with electric stimulation from a domestic bee farm in Cikurutung Street, Bandung, West Java using an electrical venom device (Gunnison, 1966; Markovic and Molnar, 1954; Nobre, 1990; Palmer, 1961). This tool is used because the bees do not lose their lives and sting and are able to operate normally. Therefore, electrical current method is currently the safest BV collection process (de Graaf et al., 2020). This tool, which is generally stored in a $80^{\circ} \mathrm{C}$ freezer, comprises of a $2 \mathrm{~A}$ battery with $12-15 \mathrm{~V}, 1000 \mathrm{~Hz}$ electrical impulse generation, electrical stimulator, and glass slide (Bogdanov, 2016). We conduct a morphological confirmation of the bee farm claims.

\section{Melittin Purification}

Hanna instruments were used to dilute $62.8 \mathrm{mg} \mathrm{BV}$ into $1 \mathrm{~mL}$ of deionized water and centrifuged (Gyrozen, South Korea) with 3,000 rpm at $4 \circ \mathrm{C}$ for 20 minutes. The substance is further microfiltered with a $0.2 \mu \mathrm{m}$ filter (GE Healthcare, China) to remove impurities such as debris, bee pollen, and glue (Teoh et al., 2017).

The solution is also purified using 5 mL HisTrap ${ }^{\circledR}$ SP HP column (Cytiva Cat no.17-1152-01), at a high-performance protein cation exchange chromatography (CEX). The column is attached to ÄKTA Start System (Cytiva Cat no. 29022094), which is a protein purification system. ÄKTA start is controlled with UNICORN start 1.1 programs, which also functions to detect protein based on its absorbance unit (AU). The purification column is chosen based on the isoelectric point ( $\mathrm{pI}$ ) of Melittin. At $\mathrm{pH} 10$ (Habermehl, 1981), a strong cation column with negatives charges is chosen, using sodium phosphates with a $\mathrm{pH}$ of 6 as buffer (Teoh et al., 2017). Binding buffer consistss of 50 mM sodium phosphates (Merck, Germany) and disodium phosphatase (Merck, Germany) each. Elution buffer has the same composistion with binding buffer, with an addition of $1 \mathrm{M} \mathrm{NaCl}$ to prevent nonspecific bindings. Both binding and elution buffer are measured with $\mathrm{pH}$ meter (Mettler Toledo, Indonesia) and adjusted at $\mathrm{pH} 6$ with the addition of $1 \mathrm{M} \mathrm{HCl}$ (Merck, Germany) and $1 \mathrm{M} \mathrm{NaOH}$ (Merck, Germany) accordingly. The buffer then vacuums degasification (Value, Indonesia) and microfiltered with $0.45 \mu \mathrm{m}$ filter (GE Healthcare, China) to remove debris and soluble gas.

ÄKTA start system needs to be purged first with binding buffer (buffer A), before loading the sample. Furthermore, the pump speed is set to $1 \mathrm{~mL} / \mathrm{min}$ with the BV filtered and centrifuge to keep the buffer A running at $100 \%$ until the first peak ends. There are three elution steps with elution buffer (buffer B) of 55, 90 and 100\% with each sample diluted and separately stored at the $-80{ }^{\circ} \mathrm{C}$ freezer (Teoh et al., 2017).

\section{Melittin Screening and Measurement}

The multiple samples from ÄKTA start system are first tested with sodium dodecyl sulfate-polyacrylamide gel electrophoresis (SDS-PAGE) (Laemmli, 1970), to identify and confirm the solution. Melttin mass, measured with Fourier transform mass spectrometry (FT-MS), is $\sim 2.8 \mathrm{kDa}$ (Horn et al., 2000). Then $20 \mu \mathrm{L}$ sample is mixed with $20 \mu \mathrm{L}$ Laemlli buffer (Sigma Aldrich, India) then loaded into each well of $17.5 \%$ polyacrylamide gel (BioRad, USA). Meanwhile, for 7.5-203 kDa marker (BioRad, USA) only $10 \mu \mathrm{L}$ loaded into the gel. The gel is tun on $150 \mathrm{~V}$ for 45 minutes. The gel was submerged in coomasie blue for 20 minutes. Furthermore, the solution was destained using a destaining solution of $250 \mathrm{~mL}$ methanol (Merck, Germany) $70 \mathrm{~mL}$ acetic acid (Merck, Germany), and $680 \mathrm{~mL}$ dH2O.

Then the confirmed melittin extract are measured with lowry protein assay (Lowry et al., 1951) with NanoDrop ${ }^{\mathrm{TM}}$ One Microvolume UV-Vis Spectrophotometer (ThermoFisher Scientific, USA). Lowry reagents are made by combining reagent $A$ and $B$ at a 50:1 ratio. Reagent $A$ is made by diluting $2 \% \mathrm{Na} 2 \mathrm{CO} 3$ (Merck, Germany) in $0.1 \mathrm{~N}$ 
$\mathrm{NaOH}$ (Merck, Germany). While Reagent B is made by diluting $0.5 \%$ CuSO4.5H2O (Merck, Germany) in 1\% potassium sodium tartrate (Merck, Germany). Bovine serum albumin (BSA) (Sigma Aldrich, India) is used to make the standard curve in consentration of $0,50,100$, $150,200,250,250,300$, and $350 \mu \mathrm{g} / \mathrm{ml}$. Add $10 \mu \mathrm{L}$ lowry reagent to $2 \mu \mathrm{L}$ samples, vortex (Velp Scientifica, China) for 30 seconds, and incubates for 10 minutes at room temperature. Furthermore, $1 \mu \mathrm{L} 1 \mathrm{~N}$ Folin-Cicocalteu reagent (Sigma Aldrich, India), and vortex are added mixed for 45 seconds, and incubated for 30 minutes at room temperature. Finally, $1.5 \mu \mathrm{L}$ of incubated sample are measured at $650 \mathrm{~nm}$ using spectrophotometer UV-VIS (Lowry et al., 1951).

\section{Brine Shrimp Lethality Test (BSLT)}

A. salina egg are hatched and illuminated in a glass tank with seawater for 48 hours (household aquarium tank and light bulb). This is followed by the transportation of 10 shrimp per test tube with seawater and BV or melittin for $\mathrm{LC}_{50}$ (lethal concentration, 50\%) measurement (Meyer et al., 1982). In addition, a solution of $0.1,1,10,50,100$ $\mu \mathrm{g} / \mathrm{mL} \mathrm{BV}$ and $0.1,1,5,10$, and $25 \mu \mathrm{g} / \mathrm{mL}$ melittin are diluted with seawater using a total volume of $500 \mu \mathrm{L}$. For negative control use $500 \mu \mathrm{L}$ of seawater, incubate the shrimp for 24 hours with constant illumination than manually count the life shrimp with a magnifying glass. Make a graph of probit and Log 10 concentration then conduct linear regression to determine a linear function (Finney, 1952; Hamidi et al., 2014). LC $_{50}$ is calculated by determining the $\mathrm{x}$ value assuming $\mathrm{y}$ equals its total variety of melittion extact.(5), as shown in equation 1-3.

$$
\begin{aligned}
& y=m x+c \\
& y=\text { variety of conentration } \rightarrow x=\frac{y-c}{m} \\
& L C_{50}=10^{x}
\end{aligned}
$$

\section{MTT Assay}

Soule et al., (1973) carried out a research on MCF-7 breast cancer cells (ATCC, USA) to determine the incubated growth medium of D-MEM (Gibco, USA), Penicilin $100 \mathrm{U} / \mathrm{mL}$ - Streptomycin $100 \mu \mathrm{g} /$ mL (Invitrogen, USA), and 10\% FBS (Hyclone, USA) at log phase. Furthermore, the harvested cultured are checked under the microscope to determine its viability (Nikon, Japan) by removing the medium and adding PBS (Gibco, USA) and trypsin (Gibco, USA) to detach the viable MCF-7 cells. Centrifuged (Tommy, Japan) with 5,000 rpm for 5 minutes is used to separate trypsin and PBS with viable MCF-7 cells used to remove the supernatant. Furthermore, the MCF-7 cells (pellet) are re-suspended and counted using hemocytometer (Sigma Aldrich, USA). 5000 viable MCF-7/ well were then left overnight at $37{ }^{\circ} \mathrm{C}$ with $5 \% \mathrm{CO}_{2}$ in an incubator (Binder, Germany), and washed with PBS to remove dead cells. Then add $100 \mu \mathrm{L}$ of BV and/or melittin with into the each well (one treatment per well) and incubate for 24 hour. Add $10 \mu \mathrm{L}$ MTT dye $(50 \mu \mathrm{g})$ added (Sigma Aldrich, USA) and incubated further for 4 hours at $37 \mathrm{oC}$ with $5 \%$ $\mathrm{CO} 2$. Then the cell is counted using hemocytometer and its optical density is measured with spectrophotometer UV-VIS at $595 \mathrm{~nm}$ to determine the viability and inhibition percentage.

$$
\begin{aligned}
& \text { Inhibition }(\%) \\
& =\left(\frac{\text { OD control culture }- \text { OD cultured with melittin }}{D \text { control culture }}\right) \times 100 \%
\end{aligned}
$$

\section{Results}

\section{Melittin Purification}

The purification of BV in accordance with Teoh et al. (2017) procedure resulted in 5 fractions of BV samples with each fraction represented in UV peak from UNICORN starting program 1.1, as shown in Figure 1. Peaks 1, 2, 3, 4 and 5 were obtained when buffer B is $0 \%$, $55 \%, 90 \%$, and $100 \%$ respectively (Peak 1 and 2 are the

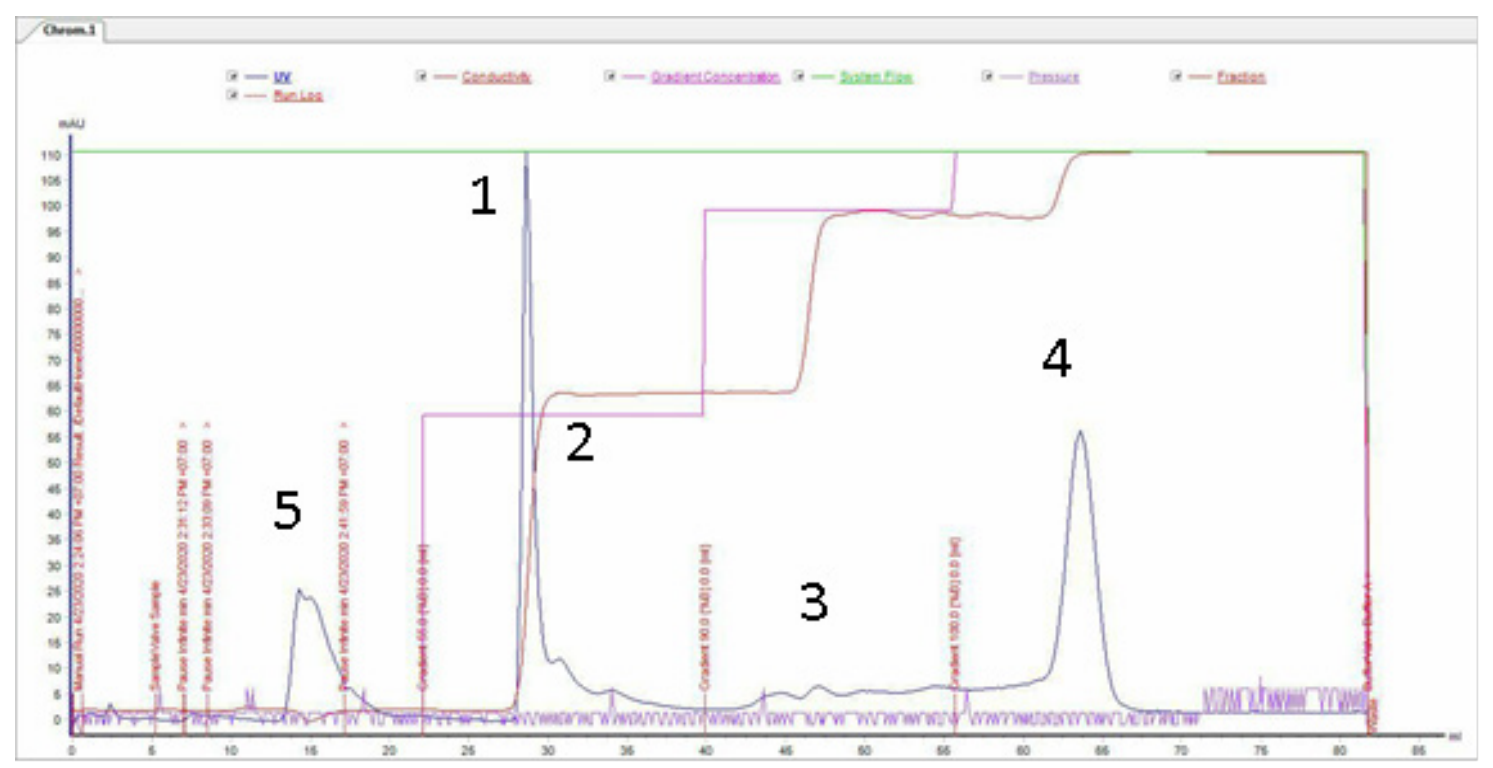

Figure 1. Apris cerana Melittin Purification Profile from ÄKTA Start System UNICRON 1.1 Program Interface. Blue : UV, Red (dotted) : Main log, Red : Counductivity, Purple : Gradient concentration 
Table 1. Lowry's Protein Assay Measurement

\begin{tabular}{lcc}
\hline Sample & A650 & Concentration $(\mu \mathrm{g} / \mathrm{mL})$ \\
\hline Peak 1 & 0.041 & 0 \\
Peak 2 & 0.173 & 142.034 \\
Peak 3 & 0.08 & 41.827 \\
Peak 4 & 0.13 & 95.432 \\
CV & 0.173 & 137.43 \\
\hline
\end{tabular}

result at $0 \%$ buffer $\mathrm{B})$. The highest peak is found in 1 and 2 and each is analyzed to confirm the samples contained in the melittin, as shown in Figure 1.

SDS-PAGE (Laemmli, 1970) and Lowry protein assay (Lowry et al., 1951) are currently the most popular methods for protein and peptide, screening and measurement processes. SDS-PAGE profile of Figure 2 shows that BV from Apis cerana has a high concentration of protein of peptide in the $\sim 19.2$ and $<7.5 \mathrm{kDa}$ region. Melittin was found in peak 4 at $<7.5 \mathrm{kDa}$, accoridng to Teoh (2017) melititn is also found in this region. Then the each of the samples measured based on a standard curve of $y=0.0015 x+0.0458$ and $R 2$ of 0.9929 . The result showed that peak 2 is the highest amount of protein at 142.032 $\mu \mathrm{g} / \mathrm{mL}$. Meanwhile melittin at peak 4 are measured at $95.432 \mu \mathrm{g} / \mathrm{mL}$ and use to determine BSLT (Table2) and MTT assay (Figure 3).

\section{Cytoxicity of Melittin from Indonesia Apis cerana}

Both BV and melittin have cytotoxicity effects, with $\mathrm{BV}$ more cytotoxic than melittin at $\leq 10 \mu \mathrm{g} / \mathrm{mL}$. However, at $25 \mu \mathrm{g} / \mathrm{mL}$ and $100 \mu \mathrm{g} / \mathrm{mL}$ melittin is far more cytotoxic than $\mathrm{BV}$ and less at $\leq 10 \mu \mathrm{g} / \mathrm{mL}$ concentration. Melittin

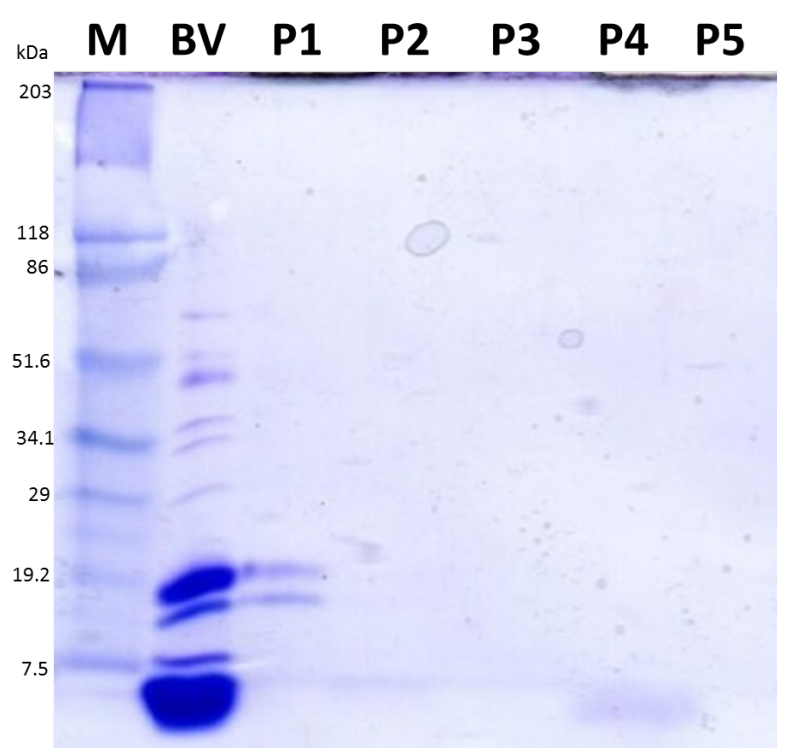

Figure 2. BV to Melittin Purification SDS-PAGE Profile. $\mathrm{M}$ : Protein marker, BV : Crude venom, P1 : Peak 1, P2 : Peak 2, P3 : Peak 3, P4 : Peak 4, and P5 : Peak 5

cytotoxicity effect rises sharply at $>10 \mu \mathrm{g} / \mathrm{mL}$, while BV is linear. It can be concluded that at lower concentrations the mixture of bioactive compounds in BV works better than melittin. Meanwhile, at higher concentrations, it becomes less efficient compared to melittin alone.

Plot between Log 10 concentration and porbit of $\mathrm{BV}$ and melittin are $\mathrm{y}=0.2854 \mathrm{x}+4.5169, \mathrm{R}^{2}=0.9303$ and $\mathrm{y}=0.8023 \mathrm{x}+4.0195, \mathrm{R} 2=0.8929$ respectively. Therefore, the calculated $\mathrm{LC}_{50}$ of both $\mathrm{BV}$ and melittin are $49.284 \mu \mathrm{g} / \mathrm{mL}$ and $16.67675 \mu \mathrm{g} / \mathrm{mL}$, respectively.

Table 2. BSLT Comparison Between Apis Cerana BV \& Melittin

\begin{tabular}{|c|c|c|c|c|c|c|c|c|}
\hline \multirow[t]{2}{*}{ Sample } & \multirow[t]{2}{*}{ Conc $(\mu \mathrm{g} / \mathrm{mL})$} & \multirow[t]{2}{*}{ Log 10 Conc } & \multirow[t]{2}{*}{ Repeats } & \multicolumn{2}{|c|}{ Larvae } & \multirow[t]{2}{*}{ Death Average } & \multirow[t]{2}{*}{ \%Death } & \multirow[t]{2}{*}{ Probi } \\
\hline & & & & Before & Death & & & \\
\hline \multirow[t]{10}{*}{$\mathrm{BV}$} & 0.1 & -1 & 1 & 10 & 1 & 2 & 20 & 4.16 \\
\hline & & & 2 & 10 & 3 & & & \\
\hline & 1 & 0 & 1 & 10 & 3 & 3.5 & 35 & 4.61 \\
\hline & & & 2 & 10 & 4 & & & \\
\hline & 10 & 1 & 1 & 10 & 5 & 4.5 & 45 & 4.87 \\
\hline & & & 2 & 10 & 4 & & & \\
\hline & 50 & 1.69897 & 1 & 10 & 4 & 4.5 & 45 & 4.87 \\
\hline & & & 2 & 10 & 5 & & & \\
\hline & 100 & 2 & 1 & 10 & 5 & 5.5 & 55 & 5.13 \\
\hline & & & 2 & 10 & 6 & & & \\
\hline \multirow[t]{10}{*}{ Melittin } & 0.1 & -1 & 1 & 10 & 0 & 0.5 & 5 & 3.36 \\
\hline & & & 2 & 10 & 1 & & & \\
\hline & 1 & 0 & 1 & 10 & 2 & 1.5 & 15 & 3.96 \\
\hline & & & 2 & 10 & 1 & & & \\
\hline & 5 & 0.69897 & 1 & 10 & 3 & 2.5 & 25 & 4.33 \\
\hline & & & 2 & 10 & 2 & & & \\
\hline & 10 & 1 & 1 & 10 & 3 & 3.5 & 35 & 4.61 \\
\hline & & & 2 & 10 & 4 & & & \\
\hline & 25 & 1.39794 & 1 & 10 & 8 & 7 & 70 & 5.52 \\
\hline & & & 2 & 10 & 6 & & & \\
\hline
\end{tabular}



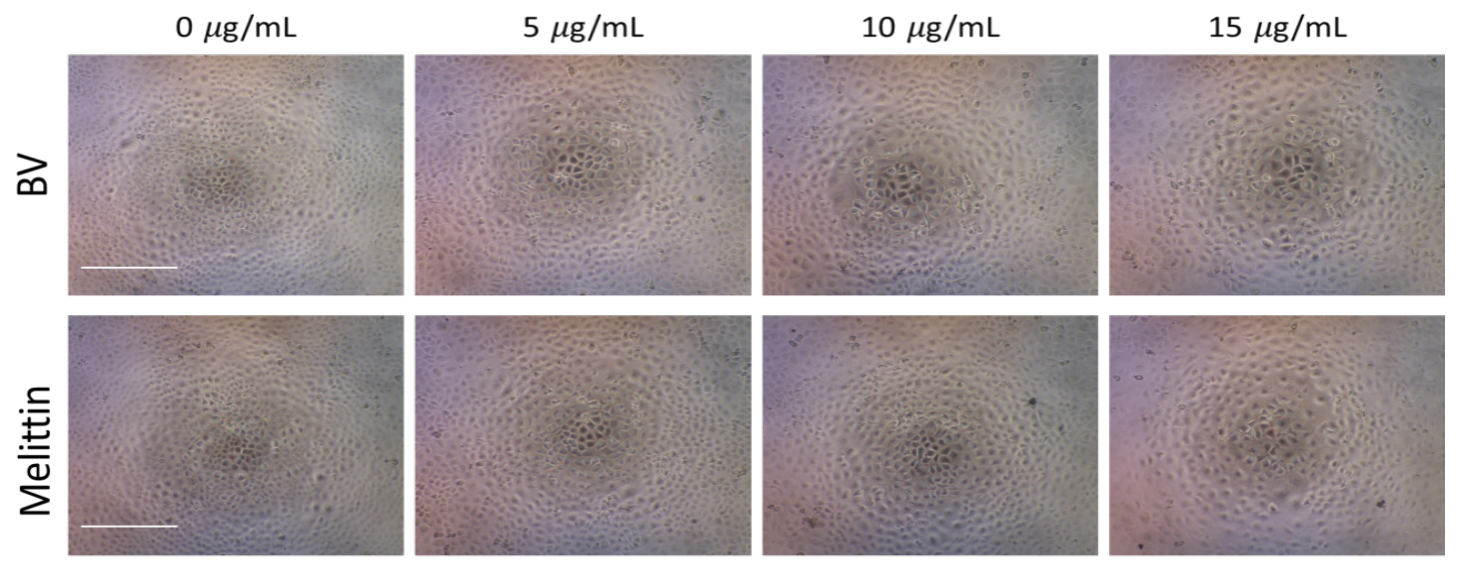

(a)

\section{MTT Assay Comparison Between Apis cerana BV \& Melittin}

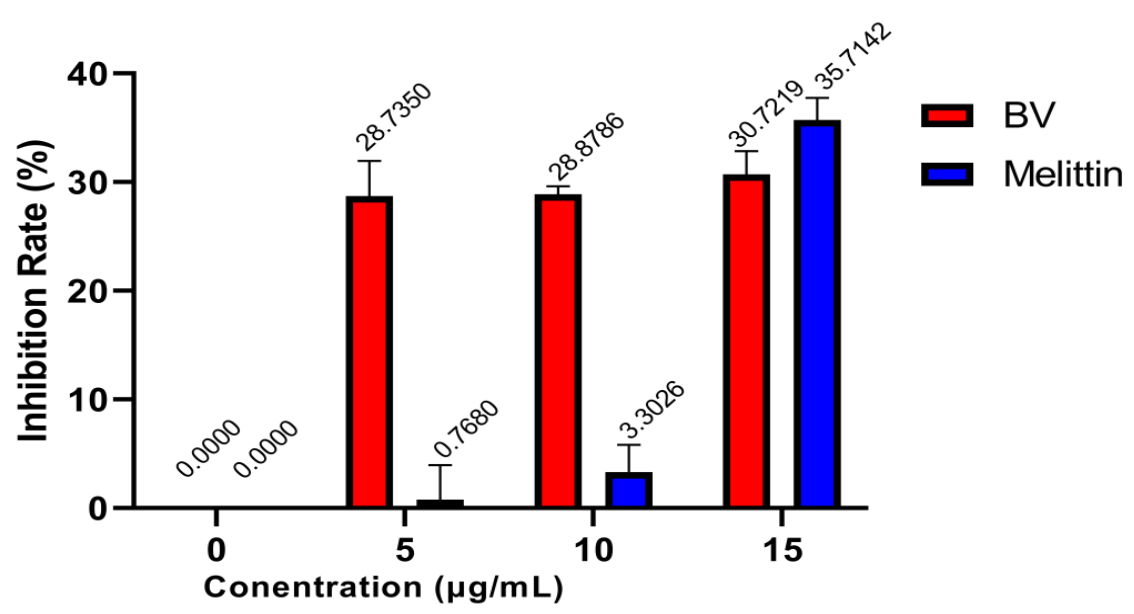

(b)

Figure 3. MTT Asasy Comparison between Apis cerana BV \& Melittin. (a) MTT assay using MCF-7 breast cancer cells cultured with the addition BV and melttin extract. The control condition for the MTT assay is when there is no BV or melittin added into the cultured. (b) The inhibition rate (\%) of varied BV and melittin concentration (each condition are replicated three times) assay.

The trend of average cell death of BV is more linear than melittin, as shown in Table 1.

\section{Anti-Breast Cancer Activity of Melittin from Indonesia Apis cerana}

MTT assay using MCF-7 shows that both BV and melittin extract inhibit breast cancer cells growth. The inhibition rates of $\mathrm{BV}$ for 5,10 and $15 \mu \mathrm{g} /$ are $28.725 \pm 0.014,28.879 \pm 0.003$, and $30.722 \pm 0.009$, respectively. Meanwhile, inhibition rate of melittin for 5, 10 and $15 \mu \mathrm{g} / \mathrm{mL}$ are $0.768 \pm 0.014,3.303 \pm 0.010$, and $35.714 \pm 0.009$, respectively, as shown in Figure 3 .

\section{Discussion}

Currently, studies on Apis melifera are more frequent compared to Apis cerana, therefore, a lot is yet to be discovered on its use in the treatment of health ailments. Other than species differences, bee's geographical factor plays an important part in the yield, composition and bioactive compounds of honey, propolis, BV, etc. Geographical factor consists of areas, climate, feed (source of flowers), etc (Hussein et al., 2019; Kolayli and Keskin, 2020). Therefore, there is need to carry out more explorative research towards other species and geographical areas. This phenomenon leads to findings of better option than A. melifera and more importantly a novel $\mathrm{BV}$, and its bioactive compounds with better performances and characteristics.

The purification method of melittin from Apis mellifera BV by Teoh (2017) are transferable for Apis cerana. There are similarities in SDS-PAGE profile of melittin found in $<7.5 \mathrm{kDa}$. Meanwhile, PLA2 (Phospholipase A2) and HYA (Hyaluronic acid), previously found in 15 and 37 $\mathrm{kDa}$ are not in Apis cerana purification profile. Instead, there is a band of protein/peptide at $19.2 \mathrm{kDa}$ (Teoh et al., 2017). The difference between SDS-PAGE profile is caused by the difference between Apis melifera and Apis cerana melittin is the 18 th amino acid of serine compare to asparagine respectively (Park et al., 2014). Other different molecular characteristics and bee's feed (source of flower) lead to different BV characteristics. Teoh (2017) carried out a research by using a lyophilized mass to produce BV (Chungjin Biotech Co.,Ltd, South Korea) instead of the traditional and manual process of harvesting it from a bee farm. This produced a cleaner material, thereby providing 
a better purification result of melittin. Figure 1 shows that UV absorbance profile is rougher with a smoother line between peaks (Teoh, 2017). Furthermore, impurities such as dust, and resin contribute to the rougher UV line.

Complex cytotoxicity test with more complex organism like mammals, such as mice, rabbit, and pig need to be analyzed and understood to gain more valid $\mathrm{LC}_{50}$ measurement. BSLT is used at the early stage of this research due to its simplicity. By using mammals we could also see the specificity, selectivity on cancer cells only, of Indonesia's Apis cerana melittin. Thus, we can also see the side-effect of using it as a breast cancer medication.

According to preliminary studies carried out by Jeong (2014), both BV and melittin inhibition rates have a similar profile in the trend at lower concentration. Furthermore, melittin has a lower concentration with anti-breast cancer activity and highly rose in $15 \mu \mathrm{g} / \mathrm{mL}$. This comparison also shows that Apis mellifera melittin has a higher anti-breast cancer activity, which is similar to BV. Previous study used a lyophilized BV and melittin compared to the natural BV used in this study. Park (2015) stated that Apis cerana melittin tend to have higher therapeutic effect with varied targets, thereby making it higher than Apis mellifera. Therefore, the purification protocol in this research is not ideal, with an inferior location compared to Apis melifera in other studies. However, the BV and melittin in this study is more efficient for other diseases, such as other form of cancer, antibacterial, antifungal, antiviral, etc.

In conclusion, Indonesia's Apis cerana melittin, based on MCF-7 MTT assay is used as an alternative for cancer treatment due to its anti-breast cancer activity. It comprises $\mathrm{LC}_{50}$ of $16.67675 \mu \mathrm{g} / \mathrm{mL}$ and inhibition rate of $35.714 \%$ for MCF-7 cells at $15 \mu \mathrm{g} / \mathrm{mL}$.

Further in vitro studies need to be conducted using mammals to elucidate anti-breast cancer using different techniques.

\section{Author Contribution Statement}

$\mathrm{KL}$ as research supervisors and made the research concept; SRAS, BW, and FA as researcher and writer; and MS as research supervisor.

\section{Acknowledgements}

\section{Ethical approval}

The animals (Apis cerana and brine shrimps; Artemia salina) used in this study were commercially sourced thus the owner's consent was not required.

\section{Funding Statement}

The authors are grateful for the grant PUTI Q2 Grant NKB-4345/UN2.RST/HKP.05.00/2020 for funding this experiment.

\section{Avaibility of Data}

Other and more data could be requested by contacting the corresponding email.

\section{Conflict of Interest}

The writers do not have any conflict of interest

\section{References}

Alalawy AI, El Rabey HA, Almutairi FM, et al (2020). Effectual Anticancer Potentiality of Loaded Bee Venom onto Fungal Chitosan Nanoparticles. Int J Polym Sci, 2020, 1-9.

Badawi JK (2021). Bee Venom Components as Therapeutic Tools against Prostate Cancer. Toxins, 13, 337.

Badria F, Fathy H, Fatehe A, et al (2017). Evaluate the cytotoxic activity of honey, propolis, and bee venom from different localities in Egypt against liver, breast, and colorectal cancer. $J$ Apither, 2, 1.

Bagyalakshmi B, Priyadarshini SL, Balamurugan A (2019). Anticancer Activity of Bee Venom against Lung Cancer Cell Line (A549 Cells) Enhanced by Iron Oxide Nanoparticles Synthesized from Syzygium Aromaticum. J Drug Deliv Ther, 9, 248-54.

Bogdanov S (2016). The Bee Venom Book, Chapter 1.

Boyiadzis M, Foon KA (2008). Approved monoclonal antibodies for cancer therapy. Expert Opin Biol Ther, 8, 1151-8.

Ceremuga M, Stela M, Janik E, et al (2020). Melittin — a natural peptide from bee venom which induces apoptosis in human leukaemia cells. Biomolecules, 10, 247.

Chen J, Guan SM, Sun W, et al (2016). Melittin, the Major Pain-Producing Substance of Bee Venom. In Neuroscience Bulletin, 32, 265-72.

Cornara L, Biagi M, Xiao J, et al (2017). Therapeutic properties of bioactive compounds from different honeybee products. In Front Pharmacol, 8, 412.

de Graaf DC, Brochetto Braga MR, de Abreu RMM, et al (2020). Standard methods for Apis mellifera venom research. $J$ Apicul Res, 60, 1-31.

Duffy C, Sorolla A, Wang E, et al (2020). Honeybee venom and melittin suppress growth factor receptor activation in HER2-enriched and triple-negative breast cancer. NPJ Precision Oncol, 4, 1-16.

Falzone L, Salomone S, Libra M (2018). Evolution of cancer pharmacological treatments at the turn of the third millennium. In Front Pharmacol, 9, 1300.

Ferlay J, Colombet M, Soerjomataram I, et al (2021). Cancer statistics for the year 2020: an overview. Int J Cancer, 2021, 1-12.

Fidelio GD, Maggio B, Cumar, FA (1984). Interaction of myelin basic protein, melittin and bovine serum albumin with gangliosides, sulphatide and neutral glycosphingolipids in mixed monolayers. Chem Phys Lipids, 35, 231-45.

Finney DJ (1952). Probit analysis: A statistical treatment of the sigmoid response curve (2nd ed.). Cambridge University Press.

Gaber SN, Hemeda EEM, Elsayeh HAS, et al (2020). Propolis extract: A possible antiseptic oral care against multidrug-resistant non-fermenting bacteria isolated from non-ventilator hospital-acquired pneumonia. J Pure Appl Microbiol, 14, 123-31.

Gao D, Zhang J, Bai L, et al (2018). Melittin induces NSCLC apoptosis via inhibition of miR-183. Onco Targets Ther, 11, 4511-23.

Global Cancer Observatory (2021). Cancer Mortality Database : Indonesia 2020. https://gco.iarc.fr/today/data/factsheets/ populations/360-indonesia-fact-sheets.pdf.

Gunnison AF (1966). An improved method for collecting the liquid fraction of bee venom. J Apicul Res, 5, 33-6.

Habermehl GG (1981). Venomous Animals and Their Toxins. In Venomous Animals and Their Toxins, pp 184-7. Springer Berlin Heidelberg. https://doi.org/10.1007/978-3-642- 
88605-8 1.

Hait WN, Grais L, Benz C, et al (1985). Inhibition of growth of leukemic cells by inhibitors of calmodulin: Phenothiazines and melittin. Cancer Chemother Pharmacol, 14, 202-5.

Hara Y, Minami Y, Yoshimoto S, et al (2020). Anti-tumor effects of an antagonistic mAb against the ASCT2 amino acid transporter on KRAS-mutated human colorectal cancer cells. Cancer Med, 9, 302-12.

Horn DM, Zubarev RA, McLafferty FW (2000). Automated de novo sequencing of proteins by tandem high-resolution mass spectrometry. Proc Nat Acad Sci U S A, 97, 10313-7.

Huang CH, Lee KC, Doudna JA (2018). Applications of CRISPR-Cas Enzymes in Cancer Therapeutics and Detection. In Trends Cancer, 4, 499-512.

Hussain H, Hamdan N, Sim EUH (2020). Anticancer and antimicrobial peptides from medicinal plants of Borneo island in Sarawak. Adv Traditional Med, 21, 1-9.

Hussein A, El-Ansari M, Zahra A (2019). Effect of the Honeybee Hybrid and Geographic Region on the Honey Bee Venom Production. J Plant Protect Pathol, 10, 171-6.

Jamasbi E, Mularski A, Separovic F (2015). Model Membrane and Cell Studies of Antimicrobial Activity of Melittin Analogues. Curr Top Med Chem, 16, 40-5.

Jeong YJ, Choi Y, Shin JM, et al (2014). Melittin suppresses EGF-induced cell motility and invasion by inhibiting PI3K/ Akt/mTOR signaling pathway in breast cancer cells. Food Chem Toxicol, 68, 218-25.

Jo M, Park MH, Kollipara PS, et al (2012). Anti-cancer effect of bee venom toxin and melittin in ovarian cancer cells through induction of death receptors and inhibition of JAK2/STAT3 pathway. Toxicol Appl Pharmacol, 258, 72-81.

Kolayli S, Keskin M (2020). Natural bee products and their apitherapeutic applications. Stud Nat Product Chem, 66, 175-96.

Koohpar ZK, Entezari M, Movafagh A, et al (2015). Anticancer activity of curcumin on human breast adenocarcinoma: Role of Mcl-1 gene. Int J Cancer Manage, 8, e2331.

Laemmli UK (1970). Cleavage of structural proteins during the assembly of the head of bacteriophage T4. Nature, 227, 680-5.

Lee YM, Cho SN, Son E, et al (2020). Apamin from bee venom suppresses inflammation in a murine model of gouty arthritis. J Ethnopharmacol, 257, 112860.

Lima WG, de Brito JCM, Cardoso VN, et al (2021). In-depth characterization of antibacterial activity of melittin against Staphylococcus aureus and use in a model of non-surgical MRSA-infected skin wounds. Eur J Pharm Sci, 156, 105592.

Lin TY, Hsieh CL (2020). Clinical applications of bee venom acupoint injection. In Toxins, 12, 618.

Lowry OH, Rosebrough NJ, Farr AL, et al (1951). Protein measurement with the Folin phenol reagent. J Biol Chem, 193, 265-75.

Markovic O, Molnar L (1954). Isolation of and determination of bee venom. Chemicke Zvesti, 8, 80-90.

Memariani H, Memariani M (2020). Anti-fungal properties and mechanisms of melittin. In Appl Microbiol Biotechnol, 104, 6513-26.

Memariani H, Memariani M, Moravvej H, et al (2020). Melittin: a venom-derived peptide with promising anti-viral properties. Eur J Clin Microbiol Infect Dis, 39, 5-17.

Meyer BN, Ferrigni, NR, Putnam JE, et al (1982). Brine shrimp: A convenient general bioassay for active plant constituents. Planta Med, 45, 31-34.

Moga MA, Dimienescu OG, Arvătescu CA, et al (2018). Anticancer activity of toxins from bee and snake venom-an overview on ovarian cancer. In Molecules, 23, 692.

Nobre AAB (1990). Innovations: A device to provoke venom release from honey bees. Bee World, 71, 151-2.

Palmer DJ (1961). Extraction of Bee Venom for Research. Bee World, 42(9), 225-226. https://doi.org/10.1080/000577 2x.1961.11096884

Park D, Jung JW, Lee MO, et al (2014). Functional characterization of naturally occurring melittin peptide isoforms in two honey bee species, Apis mellifera and Apis cerana. Peptides, 53, 185-93.

Park D, Jung WW, Choi BS, et al (2015). Uncovering the novel characteristics of Asian honey bee, Apis cerana, by whole genome sequencing. BMC Genomics, 16. https://doi. org/10.1186/1471-2164-16-1.

Hamidi MR, Jovanova B, Panovska TK (2014). Toxicological evaluation of the plant products using Brine Shrimp (Artemia salina L.) model. Macedonian Pharmaceutical Bulletin, 60, 9-18.

Rady I, Siddiqui IA, Rady M, et al (2017). Melittin, a major peptide component of bee venom, and its conjugates in cancer therapy. In Cancer Lett, 402, 16-31.

Schweizer F (2009). Cationic amphiphilic peptides with cancerselective toxicity. Eur J Pharmacol, 625, 190-4.

Sisakht M, Mashkani B, Bazi A, et al (2017). Bee venom induces apoptosis and suppresses matrix metaloprotease-2 expression in human glioblastoma cells. Revista Brasileira de Farmacognosia, 27, 324-8.

Soman NR, Lanza GM, Heuser JM, et al (2008). Synthesis and characterization of stable fluorocarbon nanostructures as drug delivery vehicles for cytolytic peptides. Nano Lett, 8, 1131-6.

Soule HD, Vazquez J, Long A, et al (1973). A human cell line from a pleural effusion derived from a breast carcinoma 1,2. J Nat Cancer Instit, 51, 1409-16.

Sung H, Ferlay J, Siegel RL, et al (2021). Global Cancer Statistics 2020: GLOBOCAN Estimates of Incidence and Mortality Worldwide for 36 Cancers in 185 Countries. $C A$ A Cancer J Clin, 71, 209-49.

Tacón A (2016). Melittin and cancer. J Apitherapy, 1, 51-4.

Teoh ACL, Ryu KH, Lee EG (2017). One-Step Purification of Melittin Derived from Apis mellifera Bee Venom. J Microbiolo Biotechnol, 27, 84-91.

Trumbeckaite S, Dauksiene J, Bernatoniene J, et al (2015). Knowledge, attitudes, and usage of apitherapy for disease prevention and treatment among undergraduate pharmacy students in Lithuania. Evidence Based Complementary Alternative Med, 2015.

Wang X, Xie J, Lu X, et al (2017). Melittin inhibits tumor growth and decreases resistance to gemcitabine by downregulating cholesterol pathway gene CLU in pancreatic ductal adenocarcinoma. Cancer Lett, 399, 1-9.

Watala C, Gwoździński K (1992). Melittin-induced alterations in dynamic properties of human red blood cell membranes. Chemico Biol Int, 82, 135-49.

Zarrinnahad H, Mahmoodzadeh A, Hamidi MP, et al (2018). Apoptotic effect of melittin purified from Iranian honey Bee Venom on human cervical cancer HeLa cell line. Int $J$ Peptide Res Ther, 24, 563-70.

Zhang S, Liu Y, Ye Y, et al (2018). Bee venom therapy: Potential mechanisms and therapeutic applications. Toxicon, 148, 64-73.

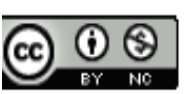

This work is licensed under a Creative Commons AttributionNon Commercial 4.0 International License. 